\section{Impact of Malocclusion on Oral Health-Related Quality of Life among Brazilian Preschool Children: a Population-Based Study}

Anita Cruz Carvalho1, Saul Martins Paiva1', Claudia Marina Viegas'1, Ana Carolina Scarpelli ${ }^{1}$, Fernanda Morais Ferreira2', Isabela Almeida Pordeus ${ }^{1}$
'Department of Pediatric Dentistry and Orthodontics, UFMG - Federal University of Minas Gerais, Belo Horizonte, MG, Brazil

${ }^{2}$ Department of Stomatology, School of Dentistry, UFPR - Federal University of Paraná, Curitiba, PR, Brazil

Correspondence: Prof. Dr. Saul Martins Paiva, Avenida Antônio Carlos, 6627, Pampulha, 31270-901 Belo Horizonte, MG, Brasil. Tel: +55-31-3409-2470. email: smpaiva@uol.com.br

\begin{abstract}
The purpose of the present study was to evaluate the impact of malocclusion on Oral Health-Related Quality of Life (OHROoL) of children and their families. A population-based cross-sectional study was carried out in Belo Horizonte, MG, Brazil. A representative sample of 1069 male and female preschoolers aged 60 to 71 months was randomly selected from public and private preschools and daycare centers. Data were collected using the B-ECOHIS. In addition, a questionnaire addressing socioeconomic and demographic data was self-administered by the parents/guardians. The criteria used to diagnose malocclusion were based on Foster and Hamilton (1969), Graboswki et al. (2007) and Oliveira et al. (2008). Descriptive, univariate and multiple Poison logistic regression analyses were carried out. The prevalence of malocclusion was observed in $46.2 \%$ of the children and deep overbite was the most prevalent type of malocclusion (19.7\%), followed by posterior crossbite (13.1\%), accentuated overjet (10.5\%), anterior open bite (7.9\%) and anterior crossbite (6.7\%). The impact of malocclusion on OHROoL was $32.7 \%$ among the children and $27.1 \%$ among the families. In Poisson multiple regression model adjusted for socioeconomic status, no significant association was found between malocclusion and OHRQoL of the children ( $\mathrm{PR}=1.09,95 \% \mathrm{Cl}: 0.96-1.24)$ and their families ( $P R=1.11,95 \% \mathrm{Cl}: 0.94-1.31)$. It is concluded that children with malocclusion in this sample did not have a negative impact on their OHROoL and of their families.
\end{abstract}

Key Words: malocclusion, child, quality of life.

\section{Introduction}

The term quality of life originates from the medical fields and is defined as "people's perception of their position in life, in the context of the culture and value systems in which they live and in relation to their goals, expectations, standards and concerns" (1). Health-related quality of life is a term used to assess how pain/discomfort and physical, psychological and social functions affect wellbeing (1).

The impact of oral health on one's quality of life is termed oral health-related quality of life (OHROoL) (2) and is defined as "the symptoms and functional and psychosocial impacts that emanate from oral diseases and disorders" (3).

Malocclusion can be considered a public health problem due to its high prevalence (4). Understanding the physical, social and physiological effects of malocclusion allows insights into its consequences regarding the daily lives of affected individuals (5). Thus, further studies are warranted to evaluate oral health and quality of life among children, especially investigations involving community samples (6). OHROoL research can be used to guide public policies and help eradicate disparities in oral health (7).

Oral diseases have a negative impact on OHROoL of school children and adolescents (8). However, children do not see their quality of life negatively impacted by other oral disorders such as malocclusion, dental trauma and developmental defects of enamel (8-11). Furthermore, most of Brazilian cross-sectional studies concerning OHROoL studies in preschool children have been performed using convenient samples and presented methodological limitations regarding data collection and analyses (10).

The aim of the present study was to evaluate the impact of malocclusion on OHROoL in a randomized representative sample of preschoolers and their families in the city of Belo Horizonte, MG, Brazil.

\section{Material and Methods}

\section{Ethical Considerations}

This study received approval from the Ethics Committee of the Federal University of Minas Gerais, Brazil. Parents/ guardians signed an informed consent allowing their children to participate in the oral examinations and provide answers to the questionnaire.

\section{Sample Characteristics}

Belo Horizonte is the capital city of the state of Minas Gerais, which is located in Southeastern Brazil. A representative cross-sectional study was carried out in Belo Horizonte. The sample consisted of 1069 Brazilian preschool children aged 60 to 71 months. Sample distribution was proportional to the total population enrolled in private 
and public preschools in each of the nine administrative districts of the city. The subjects were randomly selected using a two-stage sampling method. The first stage was the randomization of preschools and daycare centers and the second stage was the randomization of the children.

The sample size was calculated to give a standard error of 5\%. A 95\% confidence interval (CI) and a 36.46\% prevalence rate of malocclusion (12) were used for the calculation. The sample size was estimated at 671 children. As multi-stage sampling was employed, a correction factor of 1.4 was applied to increase the accuracy, leading to a minimal sample size of 939 individuals. The sample was then increased by $20 \%$ to compensate for possible losses during the data collection process, leading to a minimal sample size of 1127 individuals.

Children between 60 and 71 months of age and regularly enrolled in preschools and daycare centers were included in the sample. The following exclusion criteria were applied: presence of permanent teeth; loss of any primary tooth; dental caries affecting the integrity of the mesiodistal diameter; and previous orthodontic treatment.

\section{Pilot Study}

A pilot study was conducted to test the methods and the understanding of the instruments, and perform calibration of the examiner. The pilot study was carried out at a daycare center with 88 preschoolers, who were not included in the main sample. The results of the pilot study demonstrated that it was not necessary to alter any item on either instrument or modify the data collection process.

\section{Calibration of Examiner}

The calibration exercise consisted of a theoretical step and a clinical step. The theoretical step involved a discussion of criteria for the diagnosis of malocclusion and the analysis of eight orthodontic dental models and photographs. A specialist in orthodontics (gold standard in the theoretical framework) coordinated this step, instructing a general dentist on how to perform the examination and determine the diagnosis of malocclusion. In the clinical step, the dentist examined 28 previously selected children aged 60 to 71 months. Inter-examiner agreement was determined by comparing the examiner's results with those of the gold standard. Intra-examiner agreement was determined by a second evaluation of the models and children after a period of seven to 14 days. Cohen's kappa coefficient was used for data analysis on an alteration-by-alteration (e.g.: posterior crossbite) basis to determine the agreement between examiners.

For assessing the reproducibility of the diagnostic criteria, 10\% of the sample were re-examined during the data collection after a period of seven to 14 days.

\section{Clinical Data Collection}

The parents/guardians signed a statement of informed consent prior to the oral examinations of the children. The previously calibrated dentist performed the oral clinical examination of each child at the preschools and daycare centers. The visual inspection of the teeth was performed under natural light, in the knee-to-knee position. The examiner used individual cross-infection protection equipment and all the materials were packaged and sterilized. A dental mirror, WHO probe (Golgran Ind. e Com. Ltda., São Paulo, SP, Brazil) and dental gauze were used for the examination. Aspects of overbite, overjet and crossbite were recorded. No radiography was used for the diagnosis. The criteria for the diagnosis of malocclusion were based on Foster and Hamilton (13), Grabowski et al. (14) and Oliveira et al. (15).

Overjet was considered the horizontal overlap of the incisors. Accentuated overjet was recorded when a distance of more than $2 \mathrm{~mm}$ was found between the maxillary and mandibular incisors $(13,14)$. Overbite was considered to be the vertical overlap of the incisors when the posterior teeth were in occlusion and was considered normal when at least one of the maxillary incisors overlapped the mandibular incisors up to $2 \mathrm{~mm}$. Deep overbite was characterized by the maxillary teeth covering more than $2 \mathrm{~mm}$ of the vestibular surface of the mandibular teeth. Anterior open bite was considered the absence of a vertical overlap covering the mandibular incisors (14). Anterior crossbite was recorded when the mandibular incisors were in front of the maxillary incisors $(13,15)$. Posterior crossbite was classified based on Foster and Hamilton (13) and was recorded when the maxillary primary molars occluded in lingual relationship to the mandibular primary molars in centric occlusion.

To measure overbite and overjet, the examiner applied the WHO probe from the labial surface of the most anterior mandibular central incisor to the labial surface of the most anterior maxillary central incisor parallel to the occlusal plane. Children with at least one of the analyzed conditions (accentuated overjet, anterior crossbite, deep overbite, anterior open bite and posterior crossbite) were classified as having malocclusion (15).

\section{Non-Clinical Data Collection}

Following the clinical examination, a questionnaire addressing demographic data (child's date of birth, child's gender, parents'/guardians' schooling, place of residence, type of school, history of dental visits) was sent to the parents/guardians, along with the Brazilian version of the Early Childhood Oral Health Impact Scale.

The following socioeconomic indicators for the determination of socioeconomic status were used: monthly household income (based on the minimum wage in Brazil, 
which is roughly US \$290.47), parents'/guardians' schooling (years of study), type of preschool/daycare center (private or public) and history of dental visits (yes or no). Monthly household income was dichotomized as less than three times the minimum wage and three or more times the minimum wage.

\section{Oral Quality Health-Related of Life Assessment}

The Early Childhood Oral Health Impact Scale (ECOHIS) was developed in the United States to assess the impact of oral health problems and related treatment experience on the quality of life of children aged three to five years and their families (16). This questionnaire consists of a Child Impact Section and a Family Impact Section and contains 13 items: nine for measuring the impact of oral problems on the child and four for measuring the impact of the child's oral problems on the family. The Child Impact Section is divided into symptoms (one question), function (four questions), psychology (two questions) and self-image/ social interaction (two questions). The Family Impact Section is divided into distress (two questions) and family function (two questions). The response options employ a Likert scale: $0=$ never, $1=$ hardly ever, $2=$ occasionally, $3=$ often, $4=$ very often and $5=$ don't know. The item scores are summed for the determination of the total section score. "Don't know" responses are not included. The total score ranges from 0 to 36 on the Child Impact Section and 0 to 16 on the Family Impact Section, with higher scores denoting greater impact and/or more problems (16). In the present study, the Brazilian version was employed (ECOHIS-B), which has been validated in Brazilian Portuguese and deemed to be semantically equivalent to the original English version (17-19).

\section{Statistical Analysis}

Univariate and multiple Poisson regression analyses were performed to determine associations between the impact of oral health problems on quality of life and malocclusion (expressed as "present" or "absent") as well as all analyzed covariates. Two multiple regression models were constructed: one addressing impact on the child's quality of life (expressed as a binary outcome, i.e., scores $\leq 1$ versus scores $>1$ on the Child Impact Section of the B-ECOHIS) and another addressing impact on the family's quality of life (expressed as a binary outcome, i.e. scores $\leq 1$ versus scores $>1$ on the Family Impact Section of the $\mathrm{B}-\mathrm{ECOHIS}$ ) as the outcomes.

Descriptive analysis and the estimation of prevalence ratios based on the regression models were performed using the Statistical Package for Social Sciences (SPSS for Windows, version 18.0, SPSS Inc, Chicago, IL, USA). The level of statistical significance was set at $5 \%(p<0.05)$ for all analyses.

\section{Results}

Cohen's Kappa coefficient for inter-examiner agreement was determined by comparing the values of the examiner with the gold standard and was greater than 0.82 .

The sample was composed of 1069 preschool children between 60 and 71 months of age. The response rate was $94.9 \%$. The $5.1 \%$ loss was due to absence from school on the day of the oral examination and refusal to be examined. Table 1 displays the characterization of the sample and the frequency distribution of the preschool children according to demographic, socioeconomic and clinical data.

Most of the children (61.8\%) were between 60 and 65 months of age; $53.3 \%$ were boys $(n=570)$; and $65.9 \%$ $(n=704)$ studied in public schools. Fifty two percent of the parents/guardians $(n=556)$ were between 18 and 33 years of age and $48.0 \%(n=513)$ were between 34 and 71 years of age. Most of the guardians were mothers (86.2\%), whereas $13.8 \%$ were fathers, grandparents, uncles, aunts, brothers, sisters or nannies. The majority (68.9\%) of the parents/ guardians had more than eight years of schooling (Table 1) and $74.1 \%$ reported receiving less than three times the monthly minimum wage (Table 1).

The clinical examination revealed malocclusion in $46.2 \%$ of the children. The most prevalent type of malocclusion was deep overbite, which affected $19.7 \%$ of the sample, followed by posterior crossbite (13.1\%), accentuated overjet (10.5\%), anterior open bite (7.9\%) and anterior crossbite $(6.7 \%)$. A total of $43.8 \%$ of the sample had dental caries and $48.7 \%$ exhibited dental trauma (Table 1).

The prevalence of a negative impact of oral health status on quality of life was $32.7 \%$ among the children and $27.1 \%$ among the families. The univariate analysis revealed no significant association ( $p>0.05$ ). between malocclusion and the negative impact on the OHROoL of the children (Table 1) and their families (Table 2) This finding was confirmed by the multiple regression model adjusted for dental caries, age of parents/guardians, history of dental visits (yes or no), assessment of parents/guardians regarding the child's general health and type of preschool/daycare center (private or public) ( $\mathrm{PR}=1.09,95 \% \mathrm{Cl}$ : 0.96 to 1.24 for Child Impact Section; PR=1.11; 95\% IC: 0.94 to 1.31 for Family Impact Section) (Table 3).

\section{Discussion}

Health models suggest that wellbeing and quality of life are the products of interactions among health conditions and personal and environmental factors and are not a response to the severity of clinical condition (20). The present study lends support to this notion. Furthermore, the negative impact on the quality of life of children and their families may be explained by such health models. A previous study comparing children with oligodontia to those 
Table 1. Frequency distribution of preschool children according to demographic, socioeconomic and clinical characteristics and impact of child's oral conditions on quality of life ( $\mathrm{n}=1069)$; Belo Horizonte, MG, Brazil, 2010

\begin{tabular}{|c|c|c|c|c|c|c|}
\hline \multirow{2}{*}{ Variables } & \multicolumn{2}{|c|}{ Frequency } & \multicolumn{2}{|c|}{ Impact on quality of life } & \multicolumn{2}{|c|}{ Univariate Poisson Regression } \\
\hline & $n$ & $\%$ & No Impact (\%) & lmpact (\%) & PR & $\mathrm{Cl}(95 \%)$ \\
\hline \multicolumn{7}{|l|}{ Child characteristics } \\
\hline \multicolumn{7}{|l|}{ Age (months) } \\
\hline $60-65$ (ref) & 661 & 61.8 & $376(63.0)$ & $285(60.4)$ & \multirow{2}{*}{1.06} & \multirow{2}{*}{$0.92-1.22$} \\
\hline $66-71$ & 408 & 38.2 & $221(37.0)$ & $187(39.6)$ & & \\
\hline \multicolumn{7}{|l|}{ Gender } \\
\hline Boys (ref) & 570 & 53.3 & $326(54.6)$ & $244(51.7)$ & \multirow{2}{*}{1.06} & \multirow{2}{*}{$0.93-1.22$} \\
\hline Girls & 499 & 46.7 & $271(45.4)$ & $228(48.3)$ & & \\
\hline \multicolumn{7}{|l|}{ Type of preschool } \\
\hline Private (ref) & 365 & 34.1 & $245(41.0)$ & $120(25.4)$ & \multirow{2}{*}{1.52} & \multirow{2}{*}{$1.29-1.79$} \\
\hline Public & 704 & 65.9 & $352(59.0)$ & $352(74.6)$ & & \\
\hline \multicolumn{7}{|l|}{ Parents'/Guardians' characteristics } \\
\hline \multicolumn{7}{|l|}{ Age (years) } \\
\hline 34-71(ref) & 513 & 48.0 & $320(53.6)$ & $193(40.9)$ & \multirow{2}{*}{0.75} & \multirow{2}{*}{$0.65-0.86$} \\
\hline $18-33$ & 556 & 52.0 & $277(46.4)$ & $279(59.1)$ & & \\
\hline \multicolumn{7}{|l|}{ Relationship to child } \\
\hline Mother (ref) & 922 & 86.2 & $508(85.1)$ & $414(87.7)$ & \multirow{2}{*}{0.88} & \multirow{2}{*}{$0.71-1.08$} \\
\hline Other & 147 & 13.8 & $89(14.9)$ & $58(12.3)$ & & \\
\hline Years of schooling & & & & & & \\
\hline >8 years (ref) & 737 & 68.9 & $430(72.0)$ & $307(65.0)$ & & $104-127$ \\
\hline$\leq 8$ years & 332 & 31.1 & $167(28.0)$ & $165(35.0)$ & 1.19 & $1.04-1.37$ \\
\hline Monthly household income" & & & & & & \\
\hline$>3$ times the minimum wage (ref) & 277 & 25.9 & $186(31.2)$ & $91(19.3)$ & 146 & $122-175$ \\
\hline$\leq 3$ times the minimum wage & 792 & 74.1 & $411(68.8)$ & $381(80.7)$ & 1.40 & $1.22-1.75$ \\
\hline Child's clinical disease status & & & & & & \\
\hline Posterior cross bite & & & & & & \\
\hline Absent (ref) & 929 & 86.9 & $504(84.4)$ & $425(90.0)$ & 073 & $057 \quad 093$ \\
\hline Present & 140 & 13.1 & $93(15.6)$ & $47(10.0)$ & 0.15 & נד. \\
\hline Overjet & & & & & & \\
\hline Normal (ref) & 957 & 89.5 & $535(89.6)$ & $422(89.4)$ & 101 & 091 \\
\hline Accentuated & 112 & 10.5 & $62(10.4)$ & $50(10.6)$ & 1.01 & $0.81-1.25$ \\
\hline Anterior Open bite & & & & & & \\
\hline Absent (ref) & 985 & 92.1 & $556(93.1)$ & $429(90.9)$ & 117 & $094-146$ \\
\hline Present & 84 & 7.9 & $41(6.9)$ & $43(9.1)$ & 1.11 & $0.34-1.40$ \\
\hline Deep Overbite & & & & & & \\
\hline Absent (ref) & 858 & 80.3 & $486(81.4)$ & $372(78.8)$ & 109 & $092-128$ \\
\hline Present & 211 & 19.7 & $111(18.6)$ & $100(21.2)$ & ك 1.0 & 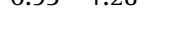 \\
\hline Anterior crossbite & & & & & & \\
\hline Absent (ref) & 997 & 93.3 & $564(94.5)$ & $433(91.7)$ & 121 & $009-156$ \\
\hline Present & 72 & 6.7 & $33(5.5)$ & $39(8.3)$ & 1.24 & $0.99-1.50$ \\
\hline Malocclusion & & & & & & \\
\hline Absent (ref) & 575 & 53.8 & $328(54.9)$ & $247(52.3)$ & & 092 \\
\hline Present & 494 & 46.2 & $269(45.1)$ & $225(47.7)$ & 1.06 & $0.92-1.21$ \\
\hline Dental Caries & & & & & & \\
\hline Absent (ref) & 601 & 56.2 & $408(68.3)$ & $193(40.9)$ & 185 & $161-213$ \\
\hline Present & 468 & 43.8 & $189(31.7)$ & $279(59.1)$ & 1.03 & $1.01-2.15$ \\
\hline Dental Trauma & & & & & & \\
\hline Absent (ref) & 548 & 51.3 & $318(53.3)$ & $230(48.7)$ & & \\
\hline Present & 521 & 48.7 & $279(46.7)$ & $242(51.3)$ & 1.10 & $0.96-1.26$ \\
\hline
\end{tabular}

$\mathrm{PR}=$ prevalence ratio; $\mathrm{Cl}=$ confidence interval; Ref: reference. * Brazilian minimum wage, unit for measuring income, corresponds to $\$$ US 290.47. 
Table 2. Frequency distribution of preschool children according to demographic, socioeconomic and clinical characteristics and impact of child's oral conditions on family's quality of life $(n=1069)$; Belo Horizonte, MG, Brazil, 2010

\begin{tabular}{|c|c|c|c|c|}
\hline \multirow{2}{*}{ Variables } & \multicolumn{2}{|c|}{ Impact on quality of life } & \multicolumn{2}{|c|}{ Univariate Poisson Regression } \\
\hline & No Impact (\%) & Impact (\%) & PR & $\mathrm{Cl}(95 \%)$ \\
\hline \multicolumn{5}{|c|}{ Child characteristics } \\
\hline \multicolumn{5}{|l|}{ Age (months) } \\
\hline $60-65$ (ref) & $464(62.4)$ & $197(60.4)$ & \multirow{2}{*}{1.06} & \multirow{2}{*}{$0.88-1.27$} \\
\hline $66-71$ & $279(37.6)$ & $129(39.6)$ & & \\
\hline \multicolumn{5}{|c|}{ Gender } \\
\hline Boys (ref) & $393(52.9)$ & $177(54.3)$ & \multirow{2}{*}{0.96} & \multirow{2}{*}{$0.80-1.15$} \\
\hline Girls & $350(47.1)$ & $149(45.7)$ & & \\
\hline \multicolumn{5}{|c|}{ Type of preschool } \\
\hline Private (ref) & $289(38.9)$ & $76(23.3)$ & \multirow{2}{*}{1.70} & \multirow{2}{*}{$1.36-2.13$} \\
\hline Public & $454(61.1)$ & $250(76.7)$ & & \\
\hline \multicolumn{5}{|c|}{ Parents'/Guardians' characteristics } \\
\hline \multicolumn{5}{|c|}{ Age (years) } \\
\hline 34-71(ref) & $381(51.3)$ & $132(40.5)$ & \multirow{2}{*}{0.74} & \multirow{2}{*}{$0.61-0.89$} \\
\hline $18-33$ & $362(48.7)$ & $194(59.5)$ & & \\
\hline \multicolumn{5}{|c|}{ Relationship to child } \\
\hline Mother (ref) & $640(86.1)$ & $282(86.5)$ & \multirow{2}{*}{0.98} & \multirow{2}{*}{$0.75-1.28$} \\
\hline Other & $103(13.9)$ & $44(13.5)$ & & \\
\hline \multicolumn{5}{|c|}{ Years of schooling } \\
\hline$>8$ years $(\mathrm{ref})$ & $539(72.5)$ & $198(60.7)$ & \multirow{2}{*}{1.43} & $190 \quad 171$ \\
\hline$\leq 8$ years & $204(27.5)$ & $128(39.3)$ & & $1.20-1.11$ \\
\hline & Monthly & come $^{*}$ & & \\
\hline$>3$ times the minimum wage (ref) & $218(29.3)$ & $59(18.1)$ & 159 & 12320 \\
\hline$\leq 3$ times the minimum wage & $525(70.7)$ & $267(81.9)$ & 1.58 & $1.23-2.02$ \\
\hline & Child's cl & status & & \\
\hline & Post & & & \\
\hline Absent (ref) & $639(86.0)$ & $290(89.0)$ & 087 & $061-110$ \\
\hline Present & $104(14.0)$ & $36(11.0)$ & 0.82 & $0.61-1.10$ \\
\hline & & & & \\
\hline Normal (ref) & $670(90.2)$ & $287(88.0)$ & & \\
\hline Accentuated & 73 (9.8) & $39(12.0)$ & 1.16 & $0.88-1.52$ \\
\hline & Ant & & & \\
\hline Absent (ref) & $685(92.2)$ & $300(92.0)$ & 101 & $072 \quad 141$ \\
\hline Present & $58 \quad(7.8)$ & $26 \quad(8.0)$ & 1.01 & $0.13-1,41$ \\
\hline & & & & \\
\hline Absent (ref) & $599(80.6)$ & $259(79.4)$ & 105 & $084-131$ \\
\hline Present & $144(19.4)$ & 67 (20.6) & 1.05 & $0.84-1.31$ \\
\hline & Ant & & & \\
\hline Absent (ref) & $699(94.1)$ & 298 (91.4) & 120 & P 178 \\
\hline Present & $44 \quad(5.9)$ & $28 \quad(8.6)$ & 1.30 & $0.96-1 . / 6$ \\
\hline & & & & \\
\hline Absent (ref) & $407(54.8)$ & $168(51.5)$ & 109 & $091-121$ \\
\hline Present & $336(45.2)$ & $158(48.5)$ & 1.09 & $0.91-1.31$ \\
\hline & & & & \\
\hline Absent (ref) & $508(68.4)$ & $93(28.5)$ & 321 & $261-397$ \\
\hline Present & 235 (31.6) & $233(71.5)$ & 3.21 & $2.61-3.99$ \\
\hline & & & & \\
\hline Absent (ref) & $390(52.5)$ & $158(48.5)$ & 112 & 092121 \\
\hline Present & $353(47.5)$ & 168 (51.5) & 1.12 & $0.93-1.34$ \\
\hline
\end{tabular}

$\mathrm{PR}=$ prevalence ratio $\mathrm{Cl}=$ confidence interval; Ref: reference 
with malocclusion and dental decay found that the former group had a poorer quality of life (21). However, children with oligodontia had a better quality of life in comparison to those with other orofacial conditions, which may be explained by the fact that children with this condition commonly have long-term clinical and psychosocial care at hospitals since birth (21).

In the present study, malocclusion had no direct influence on the OHROoL of the children and their families. This result agrees with other Brazilian studies, which found that malocclusions did not affect the OHROoL of children or their families $(8,9,11)$. Recently, a cross-sectional study with a representative sample of children in Canoas, RS, Brazil found an association between malocclusion and negative impact on $\mathrm{OHROoL}$. The criteria used to determine malocclusion were not described in the study, which makes difficult the comparison of results (10).

The findings of the present study showed that malocclusion did not affect negatively the OHQoL of children. The findings of a previous investigation may offer an explanation as to why the answers of the children and parents/guardians indicated that malocclusion had not affected their lives. In a qualitative study evaluating cultural factors and children's oral health care in the United States, the parents stated that primary teeth will 'simply fall out anyway', underscoring the common belief that preventive care is not a priority for the deciduous dentition (22). Furthermore, there is a longstanding belief that dental health is separate from general health and should only be addressed when there is an evident problem (22). A clear understanding of how and why cultural beliefs and practices are obstacles regarding access to oral health services, would likely allow achieving greater success in breaking down such obstacles (22).
Findings reported by a Canadian study demonstrate that the ECOHIS may play a relevant role in studies comparing OHROoL in different groups of children (23). However, the present findings indicate that this measure is not sufficiently accurate for use in the clinical setting, which may explain the lack of a negative impact from malocclusion on OHROoL. In another study conducted in Brazil with 260 children two and five years of age and their parents, the authors state that, while the ECOHIS has been validated to assess the impact of general oral health problems, the questions are more suitable for assessing dental caries and traumatic dental injuries than malocclusion. The authors further state that the ECOHIS was not specifically developed to measure the impact of different types of malocclusion on OHROoL (8).

Socioeconomic factors had greater repercussion on OHRQoL than malocclusion. There are three ways to explain the link between socioeconomic status and health outcomes (24). First, the household income has a direct effect on the ability to access goods, services and resources that promote health. Second, there is an indirect mechanism in terms of differential exposure to risk factors and health behaviors. Third, the association between socioeconomic status and health may be the result of differences in psychological and psychosocial resources (24). Low-income families have poorer general and oral health and these socioeconomic factors exert an influence on responses regarding the impact of disease on quality of life (25). Some studies report a significant association between low household income and the negative impact of early childhood caries on OHRQoL, but found no significant association between malocclusion and OHRQoL (8).

It is important to recognize the limitations of the present study. The first limitation is inherent to a cross-sectional

Table 3. Poison multiple regression models for impact of malocclusion on quality of life children and families $(n=1069)$. Belo Horizonte, MG, Brazil, 2010

\begin{tabular}{llc}
\hline Variables & PR & $\mathrm{Cl}(95 \%)$ \\
\hline Child model & & $0.96-1.24$ \\
Malocclusion & 1.09 & $1.42-1.90$ \\
Dental caries & 1.64 & $1.07-1.41$ \\
Age of parents/guardians & 1.23 & $1.12-1.48$ \\
History of dental visits & 1.29 & $1.07-1.59$ \\
Assessment of parents/caregivers regarding child's general health & 1.30 & $1.12-1.58$ \\
Type of school & 1.33 & $0.94-1.31$ \\
Family model & & $2.25-3.41$ \\
$\quad$ Malocclusion & 1.11 & $1.00-1.43$ \\
Dental Caries & 2.81 & $1.30-1.91$ \\
Age of parents/guardians & 1.20 & $1.09-1.70$ \\
History of dental visits & 1.58 & 1.36 \\
Type of school & & \\
\hline
\end{tabular}

$\mathrm{PR}=$ prevalence ratio; $\mathrm{Cl}=$ confidence interval. Variables selected for multiple regression model $(\mathrm{p}<0.20)$. 
design, in which exposure and outcome are determined simultaneously and the time sequence is often impossible to define. Moreover, perceptions of quality of life may change over time. In general, people remember recent events more clearly and an information bias may exist in this type of study. Thus, in further studies it is necessary to perform longitudinal study designs, which would allow the investigation of multiple potential causes of the disease. A second point is that the impact of malocclusion on the children's OHRQoL was measured using parent's and guardian's reports. Thus, development of a specific questionnaire for measuring the impact of specific conditions (i.e., malocclusion) on OHROoL could be useful.

In the present study, malocclusion did not affect negatively the OHROoL of preschool children and their families. However, socioeconomic factors, such as type of school, parent's schooling and monthly household income, were associated with the quality of life of the children and their families.

\section{Resumo}

0 objetivo do presente estudo foi avaliar o impacto da maloclusão na OHROoL de crianças e suas familias. Um estudo transversal de base populacional foi conduzido em Belo Horizonte, Brasil. Uma amostra representativa contendo 1069 crianças dos gêneros masculino e feminino foi randomicamente selecionada, em creches e pré-escolas públicas e privadas. Os dados foram coletados através do questionário B-ECOHIS. Ademais, um questionário contendo dados socioeconômicos e demográficos foi respondido pelos pais/responsáveis das crianças. Os critérios utilizados para o diagnóstico de maloclusão foram baseados nos estudos de Foster e Hamilton (1969), Graboswki et al. (2007) e Oliveira et al. (2008). Análises descritivas, univariadas e regressão logistica múltipla de Poisson foram realizadas. A prevalência de maloclusão foi observada em $46,2 \%$ das crianças, sendo a mordida profunda o tipo de maloclusão mais frequente $(19,7 \%)$, seguido de mordida cruzada posterior $(13,1 \%)$, sobressaliência acentuada $(10,5 \%)$, mordida aberta anterior $(7,9 \%)$ e mordida cruzada anterior $(6,7 \%)$. A prevalência do impacto da maloclusão na OHRQoL foi de $32,7 \%$ nas crianças e $27,1 \%$ nas famílias. No modelo de regressão múltipla ajustado para o status socioeconômico, não se observou associação significante entre maloclusão e $\mathrm{OHRO}$ oL das crianças $(\mathrm{PR}=1.09,95 \% \mathrm{Cl}$ : $0,96-1,24)$ e de suas familias ( $P R=1,11,95 \% \mathrm{Cl}: 0,94-1,31)$. Conclui-se que as crianças que apresentaram maloclusão nesta amostra, não apresentaram impacto negativo na sua $\mathrm{OHRO}$ oL e nem de suas famílias.

\section{Acknowledgments}

This study was supported by the National Council for Scientific and Technological Development (CNPq), the Ministry of Science and Technology and the Research Foundation of the State of Minas Gerais (FAPEMIG), Brazil.

\section{References}

1. Study protocol for the World Health Organization project to develop a Quality of Life assessment instrument (WHOOOL). Qual Life Res 1993;2:153-159.

2. Geels LM, Kieffer JM, Hoogstraten J, Prahl-Andersen B. Oral healthrelated quality of life of children with craniofacial conditions. Cleft Palate Craniofac J 2008;45:461-467.

3. Locker D, Matear D, Stephens M, Jokovic A. Oral health-related quality of life of a population of medically compromised elderly people.
Community Dent Health 2002;19:90-97.

4. Peres KG, Traebert ES, Marcenes W. Differences between normative criteria and self-perception in the assessment of malocclusion. Rev Saude Publica 2002;36:230-236.

5. Cunningham SJ, Hunt NP. Quality of life and its importance in orthodontics. J Orthod 2001;28:152-158.

6. Slade GD, Reisine ST. The child oral health impact profile: current status and future directions. Community Dent Oral Epidemiol 2007;35:50-53.

7. Sischo L, Broder HL. Oral Health-Related Quality of Life: What, Why, How, and Future Implications. J Dent Res 2011;90:1264-1270.

8. Abanto J, Carvalho TS, Mendes FM, Wanderley MT, Bönecker M, Raggio DP. Impact of oral diseases and disorders on oral health-related quality of life of preschool children. Community Dent Oral Epidemiol 2011;39:105-114.

9. Aldrigui JM, Abanto J, Carvalho TS, Mendes FM, Wanderley MT, Bonecker

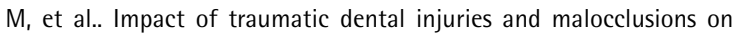
quality of life of young children. Health Qual Life Outcomes 2011;9:78.

10. Kramer PF, Feldens CA, Ferreira SH, Bervian J, Rodrigues PH, Peres MA. Exploring the impact of oral diseases and disorders on quality of life of preschool children. Community Dent Oral Epidemiol 2013;41:327-335

11. Scarpelli AC, Paiva SM, Viegas CM, Carvalho AC, Ferreira FM, Pordeus IA. Oral health-related quality of life among Brazilian preschool children. Community Dent Oral Epidemiol 2013;41:336-344.

12. Ministério da Saúde. Projeto SB Brasil, 2003: condição de saúde bucal da população brasileira: 2002-2003. Resultados principais. Brasilia: Ministério da Saúde, 2004. Available at: "http://portal.saude.gov.br/ portal/saude/visualizar_texto.cfm?idtxt=23651" Accessed November 13, 2010.

13. Foster TD, Hamilton MC. Occlusion in the primary dentition. Study of children at 2 and one-half to 3 years of age. Br Dent J 1969;126:76-79.

14. Grabowski R, Stahl F, Gaebel M, Kundt G. Relationship between occlusal findings and orofacial myofunctional status in primary and mixed dentition. Part I: Prevalence of malocclusions. J Orofac Orthop 2007;68:26-37.

15. Oliveira AC, Paiva SM, Campos MR, Czeresnia D. Factors associated with malocclusions in children and adolescents with Down syndrome. Am J Orthod Dentofacial Orthop 2008;133:489.e1-e8.

16. Pahel BT, Rozier RG, Slade GD. Parental perceptions of children's oral health: the Early Childhood Oral Health Impact Scale (ECOHIS). Health Qual Life Outcomes 2007;30:5:6.

17. Tesch FC, Oliveira BH, Leão A. Semantic equivalence of the Brazilian version of the Early Childhood Oral Health Impact Scale. Cad Saude Publica 2008;24:1897-1909.

18. Scarpelli AC, Oliveira BH, Tesch FC, Leao AT, Pordeus IA, Paiva SM. Psychometric properties of the Brazilian version of the Early Childhood Oral Health Impact Scale (B-ECOHIS). BMC Oral Health 2011;11:19.

19. Martins-Júnior PA, Ramos-Jorge J, Paiva SM, Marques LS, Ramos-Jorge ML. Validations of the Brazilian version of the Early Childhood Oral Health Impact Scale (ECOHIS). Cad Saude Publica 2012;28:367-374.

20. Wilson IB, Cleary PD. Linking clinical variables with health-related quality of life. A conceptual model of patient outcomes. JAMA 1995;273:59-65.

21. Locker D, Jokovic A, Prakash P, Tompson B. Oral health-related quality of life of children with oligodontia. Int J Paediatr Dent 2010;20:8-14.

22. Hilton IV, Stephen S, Barker JC, Weintraub JA. Cultural factors and children's oral health care: a qualitative study of carers of young children. Community Dent Oral Epidemiol 2007;35:429-438.

23. Li S, Malkinson S, Veronneau J, Allison PJ. Testing responsiveness to change for the early childhood oral health impact scale (ECOHIS). Community Dent Oral Epidemiol 2008;36:542-548.

24. Sanders AE, Spencer AJ. Childhood circumstances, psychosocial factors and the social impact of adult oral health. Community Dent Oral Epidemiol 2005;33:370-377.

25. Locker D. Disparities in oral health-related quality of life in a population of Canadian children. Community Dent Oral Epidemiol 2007;35:348356. 